\title{
Myositis Ossificans Traumatica of the Temporal Muscle: a Case Report and Literature Review Emphasizing Radiographic Features on Computed Tomography and Magnetic Resonance Imaging
}

\author{
Erika Antonia dos Anjos Ramos', Luciana Munhoz', Basílio Almeida Milani², Fernando Pando \\ de Matos $^{2}$, Emiko Saito Arita ${ }^{1}$ \\ ${ }^{1}$ Department of Stomatology, School of Dentistry, University of São Paulo, São Paulo, Brazil. \\ ${ }^{2}$ Maxillofacial Surgery Department, Hospital Municipal do Campo Limpo, São Paulo, Brazil.
}

Corresponding Author:

Luciana Munhoz

Department of Stomatology, School of Dentistry

University of São Paulo

2227 Lineu Prestes Avenue. Zip Code: 05508-000 São Paulo, SP

Brazil

Phone: +55 11 3091-7831; +55 11945425775

Fax: +55 11 3091-7831

E-mail: dra.lucimunhoz@usp.br

\begin{abstract}
Objectives: Heterotopic bone formation within a muscle is designated as 'myositis ossificans', and it is associated with multiple aetiologies, such as trauma, genetic predisposition, post-infection, or undetermined causes. When the disease develops as a result of a trauma, the myositis ossificans is classified as 'myositis ossificans traumatica'. In this case report, a case of myositis ossificans traumatica is described, emphasizing its imaging features. Additionally, a literature review of the imaging features of myositis ossificans is discussed.

Material and Methods: A 60-year old male patient presented with restricted mouth opening and pain during mastication. Multislice computed tomography and magnetic resonance imaging examinations were conducted. Case reports in the literature of myositis ossificans were searched databases from August 1984 until April 2019 using the keyword 'masticatory muscles' combined with 'myositis'; 'inflammatory myositis'; infectious myositis'; 'inflammatory muscle diseases'; 'focal myositis' and 'proliferative myositis'. Data was summarised and evaluated according to a critical appraisal checklist for case reports.

Results: Multislice computed tomography demonstrated an ectopic hyperdense area arising from the coronoid bone and within the temporal muscle. Magnetic resonance imaging demonstrated the same area with a hypointense signal. In the literature review, 53 myositis ossificans cases were identified, and 12 cases affecting the temporal muscle were found.

Conclusions: The main imaging feature of myositis ossificans is the presence of a radiopaque, hyperdense or hypointense mass in the affected muscle, which is seen on multislice computed tomography and magnetic resonance imaging, respectively. The final diagnosis is through histopathological examination, although imaging can suggest the most likely diagnosis.
\end{abstract}

Keywords: diagnostic imaging; magnetic resonance imaging; myositis ossificans, oral pathology, temporal muscle; tomography.

\footnotetext{
Accepted for publication: 28 December 2019

To cite this article:

Ramos EADA, Munhoz L, Milani BA, de Matos FP, Arita ES.

Myositis Ossificans Traumatica of the Temporal Muscle: a Case Report and Literature Review Emphasizing Radiographic Features on Computed Tomography and Magnetic Resonance Imaging

J Oral Maxillofac Res 2019;10(4):e5

URL: http://www.ejomr.org/JOMR/archives/2019/4/e5/v10n4e5.pdf doi: $\underline{10.5037 / j o m r .2019 .10405}$
} 


\section{INTRODUCTION}

Heterotopic bone formation within a muscle is designated as 'myositis ossificans' (MO) [1] ], and it is associated with multiple aetiologies, such as trauma, genetic predisposition [1]], post-infection [2], or even undetermined causes [ $\underline{3}$ ]. When the disease develops as a result of a trauma, the MO is classified as 'myositis ossificans traumatica' (MOT), which is also known as focal or proliferative myositis. MOT is frequently reported as an orthopaedic outcome of chronic trauma to muscles, and it is rarely found in craniofacial sites, such as the temporal bone [1]. Focal MO in the head and neck often occurs in a defined muscle group [4]; when the disorder predominantly affects the temporal muscle, it is known as 'MOT of temporalis'.

MOT affecting the temporal muscle is infrequent $[\underline{3}, \underline{5-14}]$, and it is unusual to have MOT affecting the temporal muscle exclusively [15-23]. Trismus is one of the chief complaints reported in MO and MOT of temporalis $[\underline{4}, \underline{15-18}, \underline{20}, \underline{21}]$, although swelling with or without pain can be present $[19,23]$.

The differential diagnosis of MO, due to its radiographic features of radiopaque areas with illdefined or infiltrative borders, primarily includes malignancies, such as sarcomas or chondrosarcomas, although other conditions may be considered, such as osteomas, osteochondromas, haemangiomas, or nodular fasciitis [24]. Hence, dentists should be aware of this unusual condition in order to determine a definitive diagnosis.

Thus, the objective of this report is to describe imaging features of a MOT of temporalis case, considering its characteristics in multislice computed tomography (MCT) and magnetic resonance imaging (MRI). Additionally, English language case reports of MO in different databases were reviewed, summarised and qualitatively assessed in order to allow for an overview of the main imaging features of $\mathrm{MO}$ in the literature.

\section{CASE DESCRIPTION AND RESULTS}

An African descendant, 60-year old male patient was referred to the Maxillofacial Surgery service (Campo Limpo Hospital, São Paulo, Brazil) due to restricted mouth opening and pain during mastication. The patient noticed the symptoms ten years before the consultation. The extraoral examination showed pain with palpation of the bilateral masticatory muscles, mainly in the temporal region, and limited mouth opening. Intraoral examination did not reveal any associated abnormalities. The patient mentioned a history of a previous cranio-facial trauma with a fracture in the frontal bone followed by trismus, but no other concomitant systemic disease.

The patient initially underwent a MCT and MRI to identify possible causes of his complaints. In the MCT examination, an ectopic hyperdense area was observed with density similar to bone tissue, as demonstrated in Figure 1. In the coronal slice (Figure 1A), a bone protuberance arising from the frontal bone was noted; the sagittal slice (Figure 1B) demonstrated the same bone protuberance arising from the frontal bone and mandible coronoid process, which was the likely aetiology of the restricted mouth opening. Axial slices (Figure 1C) showed

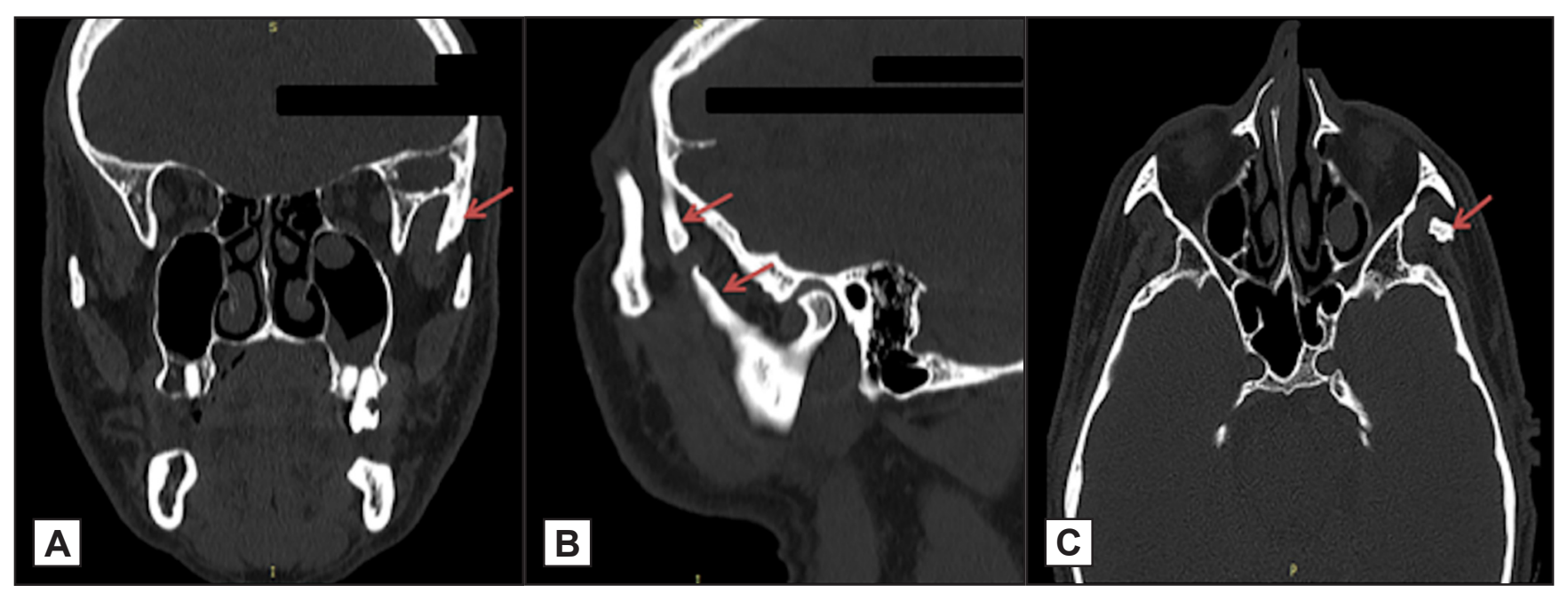

Figure 1. Initial multislice computed tomography of the case.

$\mathrm{A}=$ in frontal slice, a bone protuberance arising from the temporal bone, left size; $\mathrm{B}=$ sagittal slice, in which the protuberance can be observed both arising from frontal bone and coronoid process; $\mathrm{C}=$ in axial slice, a hyperdense area in the temporal muscle area, designated by the arrow in the pictures. 
the radiopaque mass involved in the temporal muscle area. Figure 2 demonstrates a three-dimensional view of the ectopic bone formation.

MRI showed a hypointense area arising from the coronoid bone, suggesting the presence of the calcification observed in the MCT. The MRI is demonstrated in Figure 3.

Initially, these imaging findings suggested that possible diagnoses included malignant or benign neoplasms. The patient was referred to surgical treatment with full removal of the calcified areas and coronoidectomy. Histopathologic examination of the tissue removed confirmed the diagnosis of myositis ossificans traumatica in the temporal muscle.

\section{Literature review search}

The selection of MO case reports was performed using PubMed, Embase (Excerpta Medical Database), Cochrane Central Register of Controlled Trials, Scopus, Web of Science, and Google Scholar databases. These databases were searched for English language publications from August 1984 until April 2019. Original articles and literature reviews were excluded; only human cases affecting masticatory muscles were included in the review.
The keywords (considering Medical Subject Heading terms) applied were: "myositis" AND "masticatory muscles"; "inflammatory myopathy" AND "masticatory muscles"; "inflammatory myositis" AND "masticatory muscles"; "infectious myositis" AND "masticatory muscles"; "inflammatory muscle diseases" AND "masticatory muscles"; "focal myositis" AND "masticatory muscles"; "proliferative myositis" AND "masticatory muscles", exhibited in the flow chart in Figure 4.

The reports that were not available on the selected databases, as well as the library of São Paulo University, and the São Paulo University colaborative library service, were requested from the authors. In the cases with a lack of response by the authors, the case reports were excluded from the review. The search results and summarised data, mainly regarding MO imaging features, are available in Table 1.

The literature search found 53 English language articles reporting cases of MO [1-12,15, 16, 18-57], in which ten cases were bilateral $[3,9,12,33,34,47,50]$. MO Temporalis was reported in 12 cases $[\underline{12}, \underline{15}$, $\underline{16}, \underline{18-21}, \underline{23}, \underline{28-30}, \underline{54}]$, in which one case was bilateral [12]. The medial pterygoid muscles were the most affected muscle $[\underline{1}, \underline{3}, \underline{5}, \underline{8}, \underline{26}, \underline{27}, \underline{32}, \underline{35}, \underline{38}, \underline{39}, \underline{42-}$ $\underline{46}, \underline{48}, \underline{51}, \underline{55}]$. The summarised data regarding the muscles involved are available in Figure 5.

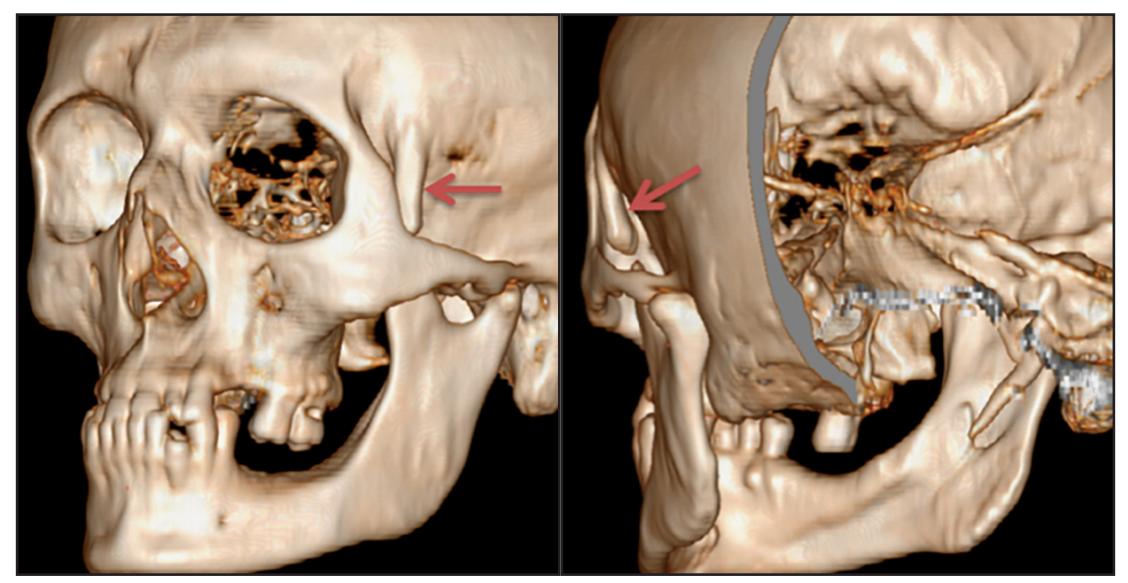

Figure 2. Three-dimensional view of the case. Ectopic bone formation is evinced by the arrow.

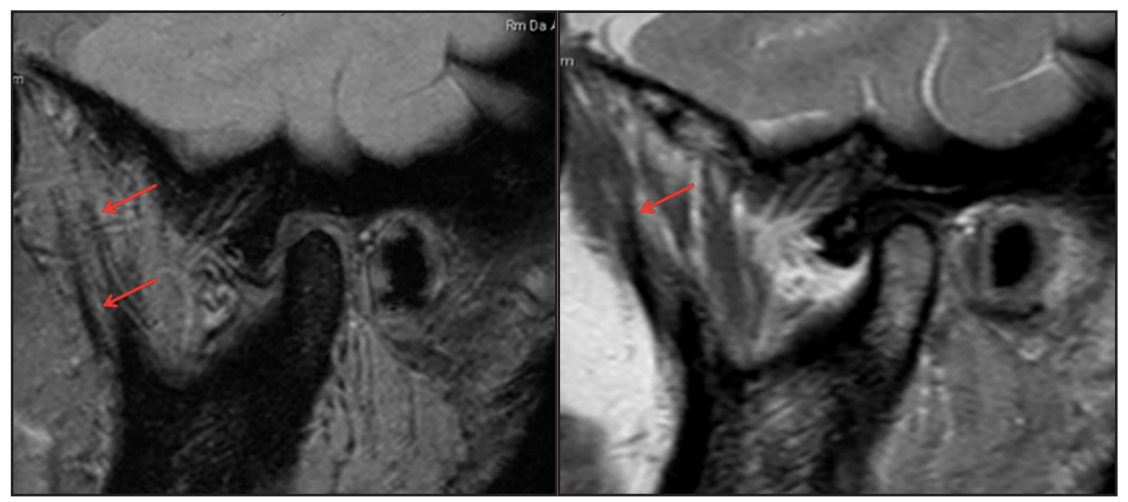

Figure 3. Magnetic resonance imaging examination. The hypointense area arising from coronoid bone. T2-weighted images, sagittal slices. 
Table 1A. Summarized data of the literature search. Authors, year of the publication, country, aetiology of the case reported, side involved, imaging examinations requested and imaging examinations main findings

\begin{tabular}{|c|c|c|c|c|c|c|c|}
\hline Author & Year & Country & Gender age & Aetiology & Side and area involved & ${\text { Imaging examinations }{ }^{a}}$ & Imaging features $^{b}$ \\
\hline Hanisch et al. [1] & 2018 & Germany & Male 28 & Inflammation/infection & Right, medial pterygoid muscles & CT & Calcification \\
\hline Jiang et al. [2] & 2015 & China & Female 42 & Inflammation/infection & Right, medial and lateral pterygoid muscles & PR, CT & $\begin{array}{l}\text { PR (panoramic radiograph): chronic periapical lesions; } \\
\text { CT: heterotopic bone formation; } \\
\text { MRI: normal anatomic structures }\end{array}$ \\
\hline Jayade et al. [3] & 2014 & India & Female 25 & Not determined & $\begin{array}{l}\text { Bilateral, medial and lateral pterygoid } \\
\text { muscles }\end{array}$ & CT, MRI & $\begin{array}{l}\text { CT: heterotopic bone formation and specks of calcification; } \\
\text { MRI: ossification and hyperostosis in the muscle }\end{array}$ \\
\hline Ratansi et al. [4] & 2017 & UK & Female 41 & Not determined & $\begin{array}{l}\text { Right, temporal region (infratemporal fossa } \\
\text { and masticatory spaces) }\end{array}$ & CTBC, MRI, PET & $\begin{array}{l}\text { CTBC: soft tissue lesion; } \\
\text { MRI: "plaque-like tissue"; } \\
\text { PET: low grade uptake in the infratemporal fossa and masticator spaces }\end{array}$ \\
\hline Reddy et al. [5] & 2014 & India & Male 21 & Trauma & Left, temporal and medial pterygoid muscles & $\mathrm{CT}$, MRI & $\begin{array}{l}\text { CT: calcified masses within temporal muscle; } \\
\text { MRI: hematoma-like lesion within temporal muscle }\end{array}$ \\
\hline Nemoto et al. [6] & 2012 & Japan & Male 39 & Trauma & $\begin{array}{l}\text { Left and right, masseter, temporal, pterygoid } \\
\text { and frontal muscles }\end{array}$ & PR, CT & $\begin{array}{l}\text { PR: calcification in the buccal muscles bilaterally; } \\
\text { CT: hyperdense areas (calcifications) within temporal, lateral pterygoid, frontal and masseter muscles }\end{array}$ \\
\hline Godhi et al. [7] & 2011 & India & Male 21 & Not determined & Right, temporal and lateral pterygoid muscles & СТ & $\begin{array}{l}\text { Calcifications involving masticatory muscles and fascia; a thick osseous bridge was observed in the region of the inferior head of the } \\
\text { right lateral pterygoid muscle }\end{array}$ \\
\hline Conner and Duffy [8] & 2009 & USA & Female 18 & Trauma (exodontia) & Right, medial pterygoid and temporal muscles & CT & Impressive calcification of the right and medial pterygoid muscles \\
\hline Yano et al. [9] & 2005 & Japan & Male 34 & Trauma & $\begin{array}{c}\text { Masseter (bilateral) and temporal muscles } \\
\text { (left) }\end{array}$ & PR, CT & $\begin{array}{l}\text { PR: calcification in the galea and scalp; } \\
\text { CT: high density calcification within bilateral masseter muscles }\end{array}$ \\
\hline St-Hilarie et al. [10] & 2004 & USA & Female 68 & Trauma (anaesthesia) & $\begin{array}{l}\begin{array}{l}\text { Left, masseter, pterygoid and temporalis } \\
\text { muscles }\end{array} \\
\end{array}$ & PR, CT & $\begin{array}{l}\text { PR: no pathological findings; } \\
\text { CT: calcification and inflammation within the temporal and pterygoid muscle }\end{array}$ \\
\hline Spinazze et al. [11] & 1998 & USA & Male 55 & Muscule stress & Left, lateral pterygoid & PR, CT, MRI & $\begin{array}{l}\text { PR: coronoid hypertrophy; } \\
\text { CT: coronoid hypertrophy, spotty diffuse a calcification in the temporal muscle nearby the coronoid process; } \\
\text { MRI: intraarticular adhesion or partial bony ankylosis }\end{array}$ \\
\hline Myoken et al. [12] & 1998 & Japan & Male 55 & $\begin{array}{c}\text { Trauma } \\
\end{array}$ & Bilateral, temporal muscle & CT & Bilateral radiopacity within temporal muscle \\
\hline Manzano et al. [18] & 2007 & Spain & Male 51 & Trauma & Right, temporal muscles & PR, CT & $\begin{array}{l}\text { PR: (ortopantomography) bone density opacity in the region of right coronoid process; } \\
\text { CT: bone density mass in the region of temporal fossa, that fussed the right temporal bone with its correspondent coronoid process }\end{array}$ \\
\hline Uematsu et al. [19] & 2005 & Japan & Female 38 & Not determined & Left, temporal muscle & $\mathrm{CT}$, MRI & $\begin{array}{l}\text { CT: high density mass in the subcutaneous tissue (no apparent calcification); } \\
\text { MRI: isointense area in the temporal muscle in T1-weighted images, heterogeneous mass in the temporal muscle }\end{array}$ \\
\hline Saka et al. [20] & 2002 & Germany & Male 33 & Trauma & Left, temporal muscle & PR, CT, MRI, USG & $\begin{array}{l}\text { PR: no pathological findings; } \\
\text { CT and MRI: not described; } \\
\text { USG: heterogeneous echogenic mass in the temporal muscle }\end{array}$ \\
\hline Mevio et al. [21] & 2001 & Italy & Female 55 & Trauma & Right, temporal muscle & CT & Area of ossification within the right temporal muscle \\
\hline Lello and Makek [22] & 1986 & Switz. & Male 34 & Trauma (accident) & Left, masseter muscle & CT & $\begin{array}{l}\text { Peripheral hyperdense mass with a hypodense central area } \\
\end{array}$ \\
\hline Wiesenfeld et al. [23] & 1985 & England & Female 10 & Not determined & Right, temporal muscle & PR, CT & $\begin{array}{l}\text { PR: calcification; } \\
\text { CT: calcification with involvement of temporal muscle }\end{array}$ \\
\hline Fité-Trepat et al, [24] & 2016 & Spain & Female 49 & $\begin{array}{l}\text { Repetitive infection } \\
\text { related to the third molar }\end{array}$ & Left, masseter muscle & PR, CT & PR (orthopantomography) and CT: well-defined calcification \\
\hline Cavalheiro et al. [25] & 2019 & Brazil & Male 71 & Trauma (gunshot) & Left, temporal, masseter and mimetic muscles & CT & Amorphous ossified formations, in a cortical/medullar pattern \\
\hline Karaali and Emeki [26] & 2018 & Turkey & Female 30 & $\begin{array}{l}\text { Trauma (third molar } \\
\text { extraction) }\end{array}$ & Right, medial pterygoid muscles & $\mathrm{CT}$, MRI & $\begin{array}{l}\text { CT: irregular heterotopic calcification; } \\
\text { MRI (temporomandibular joint): no abnormal findings }\end{array}$ \\
\hline Onishi et al. [27] & 2018 & Japan & Male 27 & Inflammation/infection & $\begin{array}{l}\text { Left, masseter, temporal, pterygoid medial } \\
\text { and lateral muscles }\end{array}$ & $\begin{array}{l}\text { CT, MRI, USG } \\
\text { (doppler) }\end{array}$ & $\begin{array}{l}\text { CT: swelling in the masticatory muscles without calcification; } \\
\text { MRI: diffusely enlarged contrast-enhanced masticatory muscles appearing hyperintense on T1; } \\
\text { USG: normal carotid, temporal and maxillary arteries }\end{array}$ \\
\hline Becker et al. [28] & 2016 & Brazil & Male 17 & Trauma (fracture) & $\begin{array}{l}\text { Right, temporal muscle } \\
\end{array}$ & CT & Cortical thickening and periosteal reaction of the coronoid process; soft tissue volume increase \\
\hline Damian et al. [29] & 2016 & Romania & Female 22 & Not determined & Right, temporal muscle & US & Enlarged of the muscle involved \\
\hline Wang et al. [30] & 2016 & China & Female 49 & Trauma (fall accident) & Right, temporal muscle & CT & Expanding hyperdense mass (heterotopic bone formation) \\
\hline Dermirkol et al. [31] & 2015 & Turkey & Female 64 & Trauma & Left, masseter muscle & PR, CT & $\begin{array}{l}\text { PR (panoramic radiograph) ovoid masses; } \\
\text { CT: small rounded radiolucent areas with central calcifications, within the muscle }\end{array}$ \\
\hline
\end{tabular}

${ }^{2}$ Considering only preoperative imaging examinations, according to the author's description.

bConsidering exclusively authors description.

'Systematic literature review with a description of the case report.

$\mathrm{PR}=$ plain radiograph; $\mathrm{CTBC}$ = cone-beam computed tomography; $\mathrm{CT}$ = computed tomography; $\mathrm{MRI}$ = magnetic resonance imaging; $\mathrm{USG}=$ ultrasound examination; $\mathrm{PET}=$ positron emission tomographic scan; $\mathrm{HU}=$ Hounsfield unit. 
Table 1B. Summarized data of the literature search. Authors, year of the publication, country, aetiology of the case reported, side involved, imaging examinations requested and imaging examinations main findings

\begin{tabular}{|c|c|c|c|c|c|c|c|}
\hline Author & Year & Country & Gender age & Aetiology & Side and area involved & 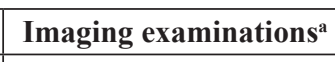 & Imaging features $^{\mathrm{b}}$ \\
\hline Kang et al. [33] & 2015 & Korea & $\begin{array}{l}\text { Case 1: female 80; } \\
\text { Case 2: female 25; } \\
\text { Case 3: female 49; } \\
\text { Case 4: female 19 }\end{array}$ & $\begin{array}{l}\text { Case 1: trauma; } \\
\text { Cases 2,3 and } 4 \text { : not determined }\end{array}$ & $\begin{array}{l}\text { Case 1: left, lateral pterygoid muscle; } \\
\text { Case 2,3 and 4: bilateral, pterygoid muscle }\end{array}$ & PR, CT, MRI & $\begin{array}{l}\text { Case } 1 \text { PR: no alterations; CT: swelling and loss of fat plane; } \\
\text { Case 2, 3 and 4: PR: no alterations (no CT performed); } \\
\text { MRI: hyperintense T2 signal }\end{array}$ \\
\hline Mashiko et al. [34] & 2015 & Japan & Male 36 & Trauma & Bilateral, masseter & $\mathrm{CT}$ & CT: calcified mass \\
\hline Torres et al. [35] & 2015 & Brazil & Female 36 & $\begin{array}{l}\text { Inflammation/ } \\
\text { infection (post-exodontia) }\end{array}$ & Right, medial pterygoid muscle & PR, CT, MRI & $\begin{array}{l}\text { PR (panoramic radiograph): calcification in mandibular ramus and pterygoid process; } \\
\text { CT: fusion of medial pterygoid muscle to the pterygoid plates; } \\
\text { MRI: calcified mass }\end{array}$ \\
\hline Ahmad et al. [36] & 2014 & Nepal & Male 30 & Trauma & Left, masseter muscle & $\mathrm{CT}$ & Irregularly outlined hyperdense lesion with dense corticated rim \\
\hline Almeida et al. [37] & 2014 & $\begin{array}{l}\text { USA/ } \\
\text { Brazil }\end{array}$ & Female 20 & Not determined & Left, lateral pterygoid muscle & CT & Calcification of the pterygoid muscle \\
\hline Boffano et al. [38] & 2014 & Italy & Female 37 & Not determined & Left, medial pterygoid muscle & $\mathrm{PR}, \mathrm{CT}$ & $\begin{array}{l}\text { PR (panoramic radiograph): radiopaque calcified region; } \\
\text { CT: irregular heterotopic calcification }\end{array}$ \\
\hline Kamalapur et al. [39] & 2014 & India & Female 20 & Not determined & $\begin{array}{l}\text { Left, temporal, lateral and medial } \\
\text { pterygoid muscles }\end{array}$ & $\mathrm{CT}$, MRI & $\begin{array}{l}\text { CT: High attenuation mass (1200 - } 1400 \mathrm{HU}) \text {; } \\
\text { MRI: Hypointense mass on T1 }\end{array}$ \\
\hline Spinzia et al. [40] & 2014 & Italy & Male 30 & Trauma (multiple fractures) & Left, lateral pterygoid muscle & $\mathrm{CT}$ & CT: significant calcification of the muscle. \\
\hline Piombino et al. [41] & 2013 & Italy & Female 62 & Not determined & Right, masseter muscle & $\mathrm{PR}, \mathrm{CT}$ & $\begin{array}{l}\text { PR (orthopantomography): radiopaque area in the maxilla; } \\
\text { CT: grossly round mass with heterogeneous density }\end{array}$ \\
\hline Choudhary et al. [42] & 2012 & India & Male 31 & Trauma & Left, medial pterygoid muscle & $\mathrm{PR}, \mathrm{CT}$ & $\begin{array}{l}\text { PR (mandible lateral oblique): radiopaque mass; } \\
\text { CT: calcification of the muscle }\end{array}$ \\
\hline Thangavelu et al. [43] & 2011 & India & Female 36 & Trauma (traumatic extraction) & Left, medial pterygoid muscle & $\mathrm{PR}, \mathrm{CT}$ & $\begin{array}{l}\text { PR (panoramic radiograph): elongated left coronoid and radiopaque structures; } \\
\text { CT: irregular ossified mass with multiple foci of central noncalcified regions of low attenuation, surrounded by a } \\
\text { peripheral ring of high density, consistent with mature bone }\end{array}$ \\
\hline Ramieri et al. [44] & 2010 & Italy & Male 64 & Not determined & Right, medial pterygoid muscle & CT, MRI & $\begin{array}{l}\text { CT: bone formation within the muscle; } \\
\text { MRI: complete lock of the temporomandibular joint }\end{array}$ \\
\hline Bansal et al. [46] & 2009 & India & Female 20 & $\begin{array}{l}\text { Trauma (dento-alveolar trauma } \\
\text { followed by extractions of all teeth) }\end{array}$ & $\begin{array}{c}\begin{array}{l}\text { Right, buccinator and medial pterygoid } \\
\text { muscles }\end{array} \\
\text {. }\end{array}$ & $\mathrm{PR}, \mathrm{CT}$ & PR (ortopantomography) and CT: calcified mass \\
\hline Kruse et al. [47] & 2009 & Switzerland & Female 35 & $\begin{array}{l}\text { After intubation and } \\
\text { chemotheraphy }\end{array}$ & Bilateral, masseter muscle & $\mathrm{PR}, \mathrm{CT}$ & $\begin{array}{l}\text { PR (panoramic radiograph): amorphous calcification within the soff tissue; } \\
\text { CT: bilateral diffuse calcification }\end{array}$ \\
\hline Rattan et al. [48] & 2008 & India & Male 45 & $\begin{array}{l}\text { Injection of absolute alcohol for } \\
\text { trigeminal neuralgia }\end{array}$ & Left, medial pterygoid muscles & $\mathrm{PR}, \mathrm{CT}$ & $\begin{array}{l}\text { PR (orthopantomography): diffuse opacity; } \\
\text { CT: irregular ossified mass }\end{array}$ \\
\hline Aoki et al. [49] & 2002 & Japan & Male 44 & Trauma (blow on the face) & $\begin{array}{l}\text { Left, masseter and lateral pterygoid } \\
\text { muscles }\end{array}$ & CT, MRI, PET & $\begin{array}{l}\text { CT: muscle calcification; } \\
\text { MRI: calcified lesions; } \\
\text { PET: spot centered around the masseter muscle }\end{array}$ \\
\hline Kim et al. [50] & 2002 & USA & Female 30 & Trauma (anaesthesia) & Bilateral, lateral pterygoid muscle & PR, CT, MRI & $\begin{array}{l}\text { PR (panoramic radiograph): calcified region; } \\
\text { CT: high attenuation within the lateral pterygoid plate; } \\
\text { MRI: no temporomandibular joint abnormalities }\end{array}$ \\
\hline Takahashi and Sato [51] & 1999 & Japan & Female 71 & Idiophatic (incidental found) & Left, medial pterygoid muscle & $\mathrm{PR}, \mathrm{CT}$ & $\begin{array}{l}\text { PR (panoramic radiograph): heterotopic calcification; } \\
\text { CT: round masses }\end{array}$ \\
\hline Geist et al. [52] & 1998 & USA & Male 44 & Trauma (fracture) & Left, masseter muscle & $\mathrm{PR}, \mathrm{CT}$ & $\begin{array}{l}\text { PR (panoramic radiograph and Reverse Towne's): bone mass in the region of the muscle; } \\
\text { CT: radiopacity }\end{array}$ \\
\hline Steiner et al. [53] & 1997 & USA & $\begin{array}{l}\text { Male } 40 / \\
\text { female } 15\end{array}$ & $\begin{array}{l}\text { Trauma (fracture)/ } \\
\text { trauma (shotgun) }\end{array}$ & $\begin{array}{l}\text { Left, masseter/ } \\
\text { left, masseter muscle }\end{array}$ & $\mathrm{PR}, \mathrm{CT} / \mathrm{CT}$ & $\begin{array}{l}\text { PR (panoramic radiograph): radiopaque mass; } \\
\text { CT: calcified periosteal hematoma within the muscle/CT: calcified mass } \\
\end{array}$ \\
\hline Naumann et al. [54] & 1993 & Germany & Male 19 & Not determined & Right, temporal muscle & MRI & $\begin{array}{l}\text { T2-weighted images showed increased signal intensity within the muscle; } \\
\text { T1-weighted images showed muscle enlarged }\end{array}$ \\
\hline Parkash et al. [55] & 1992 & India & Male 28 & Not determined & Left, medial pterygoid muscle & $\mathrm{PR}, \mathrm{CT}$ & $\begin{array}{l}\text { PR (panoramic radiograph): obliteration of the temporomandibular joint space and fan-shaped calcified mass; } \\
\text { CT: ossifying lesion, fusion between lateral pterygoid plate and medial surface of mandibular ramus }\end{array}$ \\
\hline Fujiwara et al. [56] & 1987 & Japan & Male 63 & Not determined & Right, buccinator muscle & $\mathrm{PR}, \mathrm{CT}$ & $\begin{array}{l}\text { PR: no changes; } \\
\text { CT: soft tissue mass without bone destruction }\end{array}$ \\
\hline
\end{tabular}

Considering only preoperative imaging examinations, according to the author's description.

bConsidering exclusively authors description.
$\mathrm{PR}=$ plain radiograph; $\mathrm{CTBC}=$ cone-beam computed tomography; $\mathrm{CT}$ = computed tomography; $\mathrm{MRI}$ = magnetic resonance imaging; $\mathrm{USG}=$ ultrasound examination; $\mathrm{PET}=$ positron emission tomographic scan; $\mathrm{HU}=$ Hounsfield unit. 


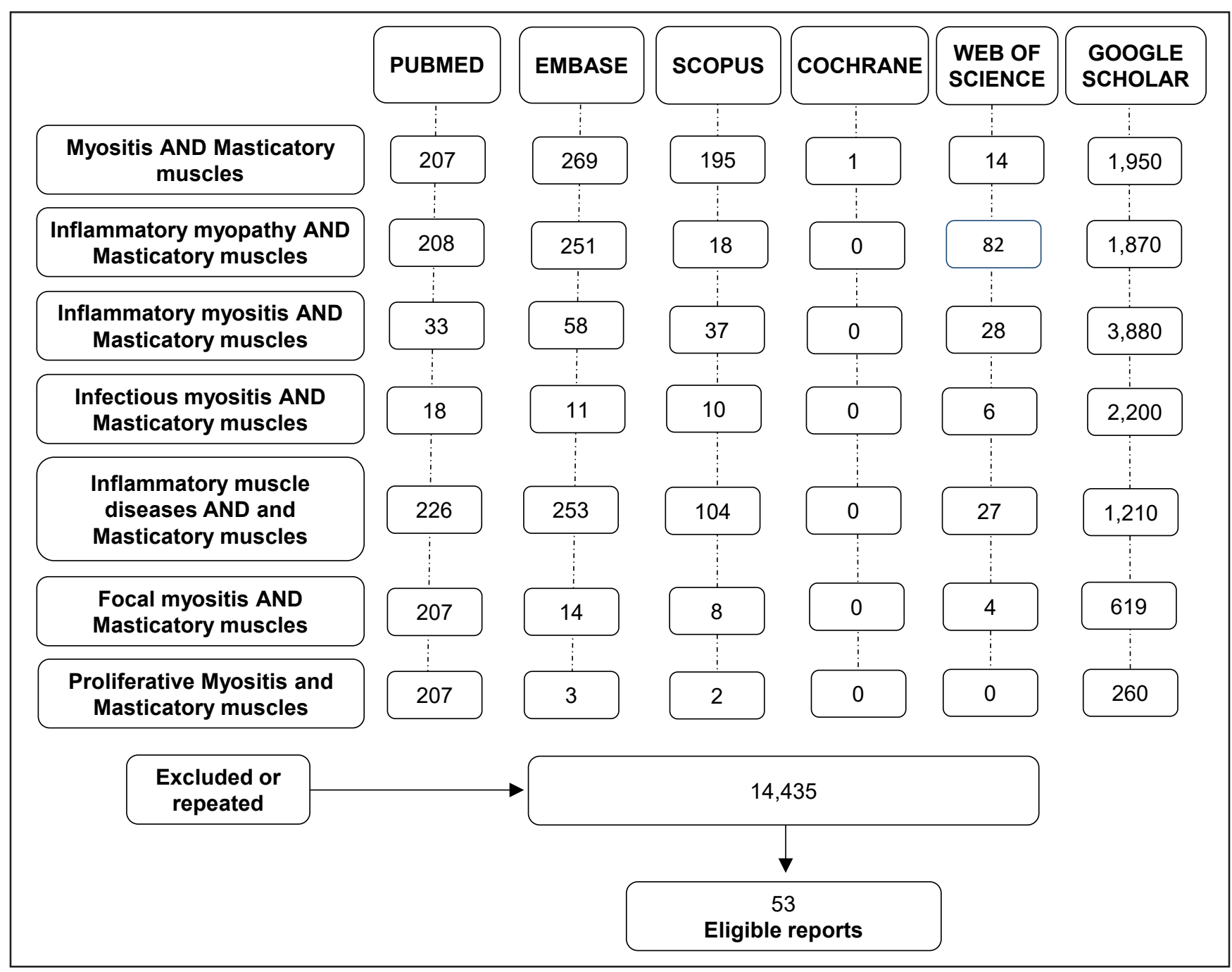

Figure 4. Flow chart of the literature search strategy.

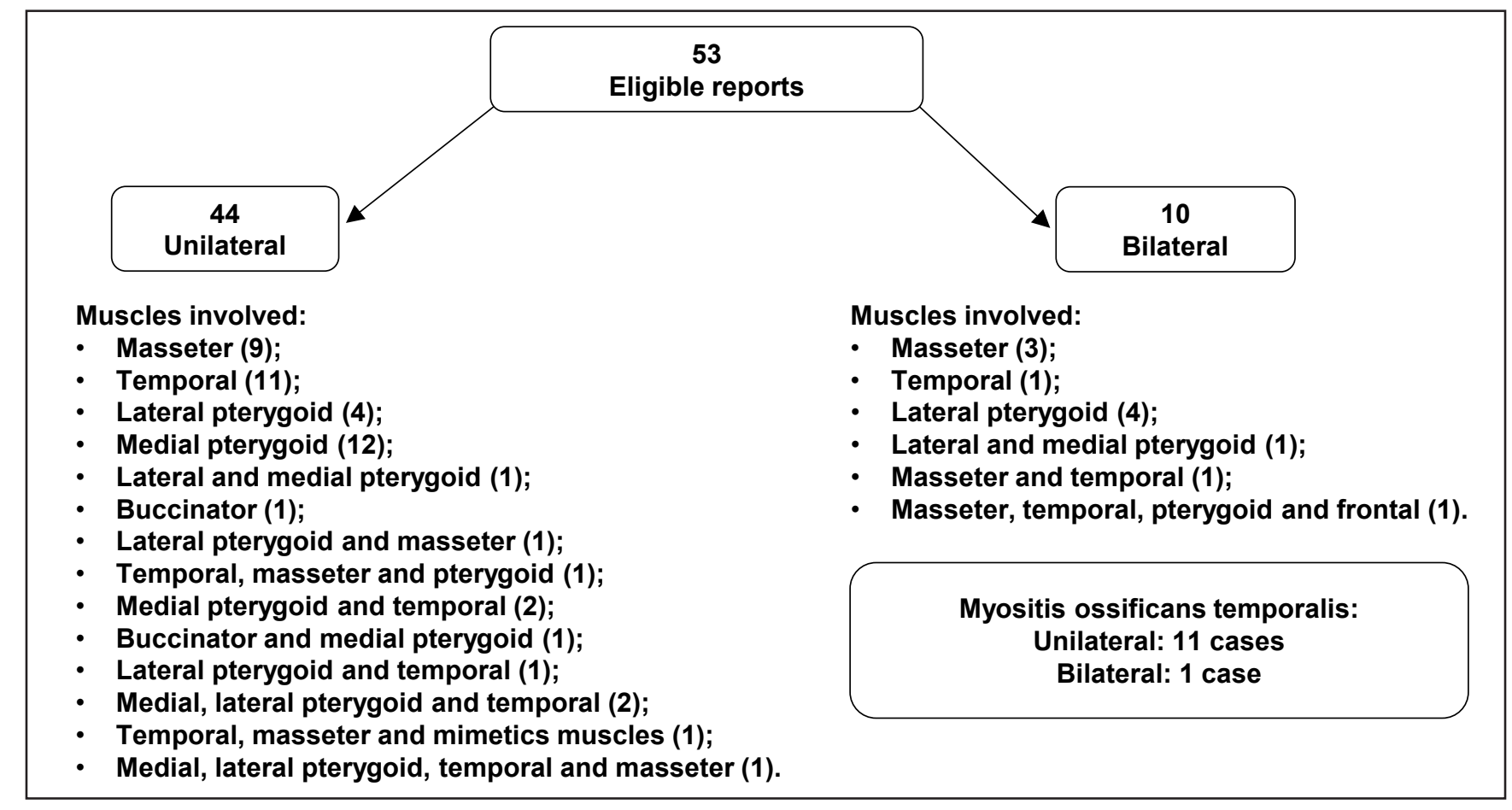

Figure 5. Summarized data pertaining to myositis ossificans most affected muscles. 
CT examinations were performed in all cases except three $[11,29,57]$. Ultrasonography (USG) was performed in two cases $[\underline{20}, \underline{27}, \underline{29}]$ and positron emission tomographic scans (PET) were used in two cases $[\underline{4}, \underline{49}]$.

The qualitative assessment of the case reports included in the literature review is exhibited in Table 2. The case reports were evaluated according to "The Joanna Briggs Institute (2017)" critical appraisal checklist for case reports [58]. The checklist consists of 8 questions. Checklist items were marked as "yes, no, unclear or not applicable". The question number 7 of the checklist was marked as "not applicable" for all the articles cited in this review as this question regards to a new condition or drug treatment [58]. Considering diagnostic imaging features qualitative evaluation (question 4: diagnostic methods), only one article was classified as "no" due to the fact that, despite of mentioning the imaging examinations applied, no description of the examinations was available, only USG [르].

Histopathology features of MOT were predominantly described as a novel formation of bone and osteoid tissue within the muscle fibers, [2] with the presence of inflammatory infiltrate, degenerative tissue and necrotic muscle fibres [4]. Only in 12 publications the histopathology examination were not proper described $[\underline{15}, \underline{16}, \underline{21}, \underline{26}, \underline{29}, \underline{33}, \underline{36}, \underline{40}, \underline{45}, \underline{47}, \underline{50}, \underline{53}]$.

\section{DISCUSSION}

Cranial MO imaging may resemble malignant neoplasms due to imaging findings, which include the appearance of an ill-defined radiopaque mass, often related to reported symptomatology, such as trismus, pain, and oedema, especially when the pathological process is associated with the masticatory muscles. Furthermore, its rapid growth, followed by significant pain and joint mobility restriction [15] leads to concern among patients and professionals. The heterotopic bone formation inherent to $\mathrm{MO}$ is also present in malignant neoplasms, such as osteosarcomas [23], and $\mathrm{MO}$ is defined as the formation of a non-neoplastic, mature, lamellar bone in the extraskeletal soft tissue. MO is usually observed in larger muscles and rarely in masticatory muscles [15]. According to the literature, $25 \%$ of cases of MO have an unknown aetiology [8] although MO can be a result of persistent inflammation or trauma [15]. In a few cases, the cause of MO was determined to be from dental origin, such as trauma during dental extraction surgery $[\underline{8}, \underline{26}, \underline{35}, \underline{43}, \underline{46}]$, repetitive infection in the third molar [24], dentoalveolar abscess [32], after a mandibular nerve block $[10,45,50]$, intubation [47], or injection of absolute alcohol for trigeminal neuralgia [48]. In the case presented in this report, the cause of MO was traumatic.

It is rare that $\mathrm{MO}$ develops on both sides of the face $[\underline{3}, \underline{9}, \underline{12}, \underline{33}, \underline{34}, \underline{47}, \underline{50}]$, which requires multiple interventions.

Conventional radiographs are often requested as the first imaging examination to investigate patient symptomatology. For craniofacial MO, the conventional examination requested is a panoramic radiograph $[\underline{15}, \underline{18}, \underline{20}, \underline{23}, \underline{24}]$, which provides a dimensional observation of the radiopaque mass near the region affected $[15,38,41]$. Further imaging examinations, including MCT and MRI are needed to determine the extension of the radiopaque mass and the muscles involved in the heterotopic bone formation. However, in early development of MO, no pathological alterations can be observed by plain radiographs $[\underline{10,56]}$.

In MCT, the extension and the limits of the radiopaque mass observed in conventional radiographs can be fully determined, although the adjacent soft tissue compromised cannot be entirely evaluated. In the literature, imaging findings are often described as hyperdense areas related to the muscles involved, designated as calcifications $[\underline{1}, \underline{5-10}, \underline{12}, \underline{15}, \underline{18}, \underline{19}, \underline{21}, \underline{23}, \underline{24}, \underline{37}]$ or heterotopic bone neoformation $[\underline{3}, \underline{16}, \underline{26}, \underline{32}, \underline{38}, \underline{41}]$. Other imaging findings were also reported, such as a hypodense central area within the hyperdense area [22], coronoid process hypertrophy [11] or coronoid process fusion with the temporal bone [18], diffuse [47] or irregular calcification [48] within the involved muscle, as well as coronoid process cortical thickening and periosteal reaction [28], and complete calcification of the muscle [45]. The absence of any calcification on CT was reported in two cases, which showed oedema in a diffuse area of the masticatory muscles [27] or no alterations [33]. Hounsfield values of the hyperdense area related to MO ranged from 1200 to 1400 . In the case presented in this report, the hyperdense area noticed on CT also showed heterotopic bone formation, with a bone protuberance arising from the temporal bone within the temporal muscle.

On MRI, which is the imaging examination that provides the most accurate soft tissue evaluation, the imaging findings described are: partial bone ankylosis [11] an isointense area in the muscle involved on T1-weighted images [19], hyperintense areas on T2-weighted images [ㅍ3], and haematoma-like findings within the muscle []ㅡ. In the present report, a hypointense area was noted arising from coronoid bone, within the temporal bone. 
Table 2. Risk of bias assessment according to "The Joanna Briggs Institute (2017)” critical appraisal checklist for case reports [58]

\begin{tabular}{|c|c|c|c|c|c|c|c|c|}
\hline Author & $\begin{array}{c}1 \\
\text { Were patient's demographic } \\
\text { characteristics clearly } \\
\text { described? }\end{array}$ & $\begin{array}{c}2 \\
\text { Was the patient's history } \\
\text { clearly described and } \\
\text { presented as a timeline? }\end{array}$ & $\begin{array}{c}3 \\
\begin{array}{c}\text { Was the current clinical } \\
\text { condition of the patient on } \\
\text { presentation clearly described? }\end{array}\end{array}$ & $\begin{array}{c}4 \\
\text { Were diagnostic tests or } \\
\text { methods and the results } \\
\text { clearly described? }\end{array}$ & $\begin{array}{c}5 \\
\text { Was the intervention(s) } \\
\text { or treatment procedure(s) } \\
\text { clearly described? }\end{array}$ & $\begin{array}{l}6 \\
\text { Was the post-intervention } \\
\text { clinical condition clearly } \\
\text { described? }\end{array}$ & \begin{tabular}{|c|} 
\\
Were the adverse events \\
or unanticipated events \\
identified and described?
\end{tabular} & $\begin{array}{c}8 \\
\text { Does the case } \\
\text { report provide } \\
\text { takeaway lessons }\end{array}$ \\
\hline Hanisch et al. [1] & Yes & Yes & Yes & Yes & \begin{tabular}{|l} 
Yes \\
\end{tabular} & Yes & NA & Yes \\
\hline Jiang et al. [2] & Yes & Yes & Yes & Yes & Yes & Yes & NA & Yes \\
\hline Jayade et al. [3] & Yes & Yes & Yes & Yes & Yes & Yes & NA & Yes \\
\hline Ratansi et al. [4] & Yes & Yes & Yes & Yes & No & No & NA & Yes \\
\hline Reddy et al. [5] & Yes & Yes & Yes & Yes & Yes & Yes & NA & Yes \\
\hline Nemoto et al. [6] & Yes & Yes & Yes & Yes & Yes & Yes & NA & Yes \\
\hline Godhi et al. [7] & Yes & Yes & Yes & Yes & Yes & Yes & NA & Yes \\
\hline Conner and Duffy. [8] & Yes & Yes & Yes & Yes & Yes & Yes & NA & Yes \\
\hline Yano et al. [9] & Yes & Yes & Yes & Yes & Yes & Yes & NA & Yes \\
\hline St-Hilarie et al. [10] & Yes & Yes & Yes & Yes & Yes & Yes & NA & Yes \\
\hline Spinazze et al. [11] & Yes & Yes & Yes & Yes & Yes & Yes & NA & Yes \\
\hline Myoken et al. [12] & Yes & Yes & Yes & Yes & Yes & No & NA & Yes \\
\hline Guarda-Nardini et al. [16] & Yes & Yes & Yes & Yes & Yes & Yes & NA & Yes \\
\hline Manzano et al. [18] & Yes & Yes & Yes & Yes & Yes & Yes & NA & Yes \\
\hline Uematsu et al. [19] & Yes & Yes & Yes & Yes & No & No & NA & No \\
\hline Saka et al. [20] & Yes & Yes & Yes & Yes & Yes & Yes & NA & Yes \\
\hline Mevio et al. [21] & Yes & Yes & Yes & Yes & Yes & Yes & NA & Yes \\
\hline Lello and Makek [22] & Yes & Yes & Yes & Yes & Yes & Yes & NA & Yes \\
\hline Wiesenfeld et al. [23] & Yes & Yes & Yes & Yes & Yes & Yes & NA & Yes \\
\hline Fité-Trepat et al, [24] & Yes & Yes & Yes & Yes & Yes & Yes & NA & Yes \\
\hline Cavalheiro et al. [25] & Yes & Yes & Yes & Yes & Yes & Yes & NA & Yes \\
\hline Karaali and Emeki. [26] & Yes & Yes & Yes & Yes & Yes & Yes & NA & Yes \\
\hline Onishi et al. [27] & Yes & Yes & Yes & Yes & Yes & Yes & NA & Yes \\
\hline Becker et al. [28] & Yes & Yes & Yes & Yes & Yes & Yes & NA & Yes \\
\hline Damian et al. [29] & Yes & Yes & Yes & $\mathrm{No}^{\mathrm{a}}$ & Yes & Yes & NA & Yes \\
\hline Wang et al. [30] & Yes & Yes & Yes & Yes & Yes & Yes & NA & Yes \\
\hline Dermirkol et al. [31] & Yes & Yes & Yes & Yes & Yes & Yes & NA & Yes \\
\hline Ferra et al. [32] & Yes & Yes & Yes & Yes & Yes & $\mathrm{No}^{\mathrm{b}}$ & NA & Yes \\
\hline Kang et al[33] & Yes & Yes & Yes & Yes & Yes & Yes & NA & Yes \\
\hline Mashiko et al. [34] & Yes & Yes & Yes & Yes & Yes & Yes & NA & Yes \\
\hline Torres et al. [35] & Yes & Yes & Yes & Yes & Yes & Yes & NA & Yes \\
\hline Ahmad et al. [36] & Yes & Yes & Yes & Yes & Yes & No & NA & Yes \\
\hline Almeida et al. [37] & Yes & Yes & Yes & Yes & Yes & Yes & NA & Yes \\
\hline Boffano et al. [38] & Yes & Yes & Yes & Yes & Yes & Yes & NA & Yes \\
\hline Kamalapur et al. [39] & Yes & Yes & Yes & Yes & Yes & Yes & NA & Yes \\
\hline Spinzia et al. [40] & Yes & Yes & Yes & Yes & Yes & Yes & NA & Yes \\
\hline Piombino et al. [41] & Yes & Yes & Yes & Yes & Yes & Yes & NA & Yes \\
\hline Choudhary et al. [42] & Yes & Yes & Yes & Yes & Yes & Yes & NA & Yes \\
\hline Thangavelu et al. [43] & Yes & Yes & Yes & Yes & Yes & Yes & NA & Yes \\
\hline Ramieri et al. [44] & Yes & Yes & Yes & Yes & Yes & No & NA & Yes \\
\hline Trautmann et al. [45] & Yes & Yes & Yes & Yes & Yes & Yes & NA & Yes \\
\hline Bansal et al. [46] & Yes & Yes & Yes & Yes & Yes & Yes & NA & Yes \\
\hline Kruse et al. [47] & Yes & Yes & Yes & Yes & Yes & Yes & NA & Yes \\
\hline Rattan et al. [48] & Yes & Yes & Yes & Yes & Yes & Yes & NA & Yes \\
\hline Aoki et al. [49] & Yes & Yes & Yes & Yes & Yes & Yes & NA & Yes \\
\hline Kim et al. [50] & Yes & Yes & Yes & Yes & Yes & Yes & NA & Yes \\
\hline Takahashi and Sato [51] & Yes & Yes & Yes & Yes & Yes & No & NA & Yes \\
\hline Geist et al. [52] & Yes & Yes & Yes & Yes & Yes & No & NA & Yes \\
\hline Steiner et al. [53] & Yes & Yes & Yes & Yes & Yes & Yes & NA & Yes \\
\hline Naumann et al. [54] & Yes & Yes & Yes & Yes & Yes & Yes & NA & Yes \\
\hline Parkash et al. [55] & Yes & Yes & Yes & Yes & Yes & Yes & NA & Yes \\
\hline Fujiwara et al. [56] & Yes & Yes & Yes & Yes & Yes & Yes & NA & Yes \\
\hline Arima et al. [57] & Yes & Yes & Yes & Yes & Yes & Yes & NA & Yes \\
\hline
\end{tabular}

The focus of this article was ultrasound examination only.

The myositis ossificans case was reported as a clinical challenge. $\mathrm{NA}=$ not applicable. 
Ultrasound examination was not usually requested; however, an USG can show the muscle enlargement [29] and muscle alterations as a heterogeneous echogenic area [20]. PET examinations, used as a complementary tool to CT and MRI, can show lowgrade uptake [4] and spots in the muscle affected by MO [49].

Besides malignant neoplasms, the differential diagnosis of MO may include pathological processes such as nodular fasciitis, haemangiomas with multiple phleboliths [31] and benign neoplasms, such as osteomas [24]. While considering these hypotheses, some imaging features should be noted. For instance, osteomas are well-defined radiopaque lesions, in contrast to MO, which often exhibits ill-defined or diffuse borders $[\underline{11}, \underline{26}, \underline{36}, \underline{38}, \underline{43}, \underline{47}, \underline{48}, \underline{57}]$, although some reports of MO did show round and well defined areas $[\underline{24}, \underline{31}, \underline{41}, \underline{51}]$. Nodular fasciitis, although of a similar aetiology to MO, does not appear as radiopaque masses [15]. Haemangiomas with multiple phleboliths can be excluded due to the main imaging feature of phleboliths, which usually include a radiopaque core with the appearance of concentric rings, also called 'laminations' $[\underline{59}, \underline{60}]$. However there is a case of MO in the masseter muscle which had imaging features similar to phleboliths [31]. When considering malignant neoplasms, despite the fact that calcifications can be noted, the destruction or invasion of adjacent structures or tissues is often observed, which is not seen in MO cases.

Other differential diagnoses should be considered when a case of MOT is under investigation, such as fibrous ankylosis in the temporal joint [11], and fibrodysplasia ossificans progressive [61], or progressive myositis ossificans, due to limited mouth opening and pain with mastication. However, these two pathologies have differences when compared to MO or even to MOT. Fibrous ankylosis in the temporal joint has its own imaging features, which include the anatomical alteration of the temporal joint and mandible head [61]. Fibrodysplasia ossificans progressive is a genetic disorder that may affect the patient in the childhood or in adult life and is recognised by two clinical features: progressive formation of extraskeletal bone and malformation of the great toes [61]. Progressive myositis ossificans is also a genetic disorder associated with several skeletal malformations, sexual disorders and deafness [21].

Finally, MO treatment usually includes surgical intervention, with the resection of the ossified mass $[\underline{3}, \underline{7}, \underline{10}, \underline{18}]$ and eventually coronoidectomy $[\underline{5}, \underline{6}, \underline{8}, \underline{9}, \underline{15}, \underline{16}, \underline{28}]$, mainly if it affects temporal muscles, as in MOT of temporalis.

The limitation of the present case report and literature review was the impossibility to evaluate all the case reports available in the literature during the period of the time selected in the methodology due to the lack of response by some authors.

\section{CONCLUSIONS}

In conclusion, the main imaging feature of myositis ossificans is the presence of a radiopaque (on plain radiographs), hyperdense (on computed tomographic examination) or hypointense (on magnetic resonance imaging) mass in the affected muscle, which is demonstrated particularly well by computed tomography and magnetic resonance imaging. The final diagnosis is through histopathological examination, although imaging examinations can direct the most likely diagnosis.

\section{ACKNOWLEDGMENTS AND DISCLOSURE STATEMENTS}

The authors report no conflicts of interest related to this study. No funding was available for this study.

\section{REFERENCES}

1. Hanisch M, Hanisch L, Fröhlich LF, Werkmeister R, Bohner L, Kleinheinz J. Myositis ossificans traumatica of the masticatory muscles: etiology, diagnosis and treatment. Head Face Med. 2018 Oct 29;14(1):23. [Medline: 30373608] [PMC free article: 6206835 ] [doi: 10.1186/s13005-018-0180-6]

2. Jiang Q, Chen MJ, Yang C, Qiu YT, Tian Z, Zhang ZY, Qiu WL. Post-infectious myositis ossificans in medial, lateral pterygoid muscles: A case report and review of the literature. Oncol Lett. 2015 Feb;9(2):920-926. [Medline: 25621069] [PMC free article: 4301508] [doi: 10.3892/ol.2014.2710]

3. Jayade B, Adirajaiah S, Vadera H, Kundalaswamy G, Sattur AP, Kalkur C. Myositis ossificans in medial, lateral pterygoid, and contralateral temporalis muscles: a rare case report. Oral Surg Oral Med Oral Pathol Oral Radiol. 2013 Oct;116(4):e261-6. [Medline: 22819452] [doi: 10.1016/j.000o.2011.11.036]

4. Ratansi R, Fabbroni G, Kanatas A. Myositis in the head and neck: challenges in diagnosis and management. Br J Oral Maxillofac Surg. 2017 Sep;55(7):722-723. [Medline: 28629834] [doi: 10.1016/j.bjoms.2017.05.018] 
5. Reddy SP, Prakash AP, Keerthi M, Rao BJ. Myositis ossificans traumatica of temporalis and medial pterygoid muscle. J Oral Maxillofac Pathol. 2014 May;18(2):271-5. [Medline: 25328311] [PMC free article: 4196299] [doi: 10.4103/0973-029X.140781]

6. Nemoto H, Sumiya N, Ito Y, Kimura N, Akizuki A, Maruyama N. Myositis ossificans traumatica of the masticatory muscles. J Craniofac Surg. 2012 Sep;23(5):e514-6. [Medline: 22976727] [doi: 10.1097/SCS.0b013e31825b33de]

7. Godhi SS, Singh A, Kukreja P, Singh V. Myositis ossificans circumscripta involving bilateral masticatory muscles. J Craniofac Surg. 2011 Nov;22(6):e11-3. [Medline: 22134307] [doi: 10.1097/SCS.0b013e31822ec7cc]

8. Conner GA, Duffy M. Myositis ossificans: a case report of multiple recurrences following third molar extractions and review of the literature. J Oral Maxillofac Surg. 2009 Apr;67(4):920-6. [Medline: 19304059] [doi: 10.1016/j.joms.2008.06.106]

9. Yano H, Yamamoto H, Hirata R, Hirano A. Post-traumatic severe trismus caused by impairment of the masticatory muscle. J Craniofac Surg. 2005 Mar;16(2):277-80. [Medline: 15750425] [doi: 10.1097/00001665-200503000-00014]

10. St -Hilaire H, Weber WD, Ramer M, Lumerman H. Clinicopathologic conference: trismus following dental treatment. Oral Surg Oral Med Oral Pathol Oral Radiol Endod. 2004 Sep;98(3):261-6. [Medline: 15356461] [doi: 10.1016/j.tripleo.2004.02.058]

11. Spinazze RP, Heffez LB, Bays RA. Chronic, progressive limitation of mouth opening. J Oral Maxillofac Surg. 1998 Oct;56(10):1178-86. [Medline: 9766544] [doi: 10.1016/S0278-2391(98)90767-4]

12. Myoken Y, Sugata T, Tanaka S. Traumatic myositis ossificans of the temporal and masseter muscle. Br J Oral Maxillofac Surg. 1998 Feb;36(1):76. [Medline: 9578265] [doi: 10.1016/S0266-4356(98)90767-7]

13. Shawkat AH. Myositis ossificans. Report of a case. Oral Surg Oral Med Oral Pathol. 1967 Jun;23(6):751-4. [Medline: 5229429] [doi: 10.1016/0030-4220(67)90364-7]

14. Hellinger MJ. Myositis Ossificans of the muscles of mastication. Oral Surg Oral Med Oral Pathol. 1965 May; 19:581-7. [Medline: 14279258] [doi: 10.1016/0030-4220(65)90398-1]

15. Schiff MJ, Meara DJ. Myositis ossificans of the temporalis muscle: case report and review of the literature. J Oral Maxillofac Surg. 2013 Nov;71(11):1893-8. [Medline: 23871468] [doi: 10.1016/j.joms.2013.05.002]

16. Guarda-Nardini L, Piccotti F, Ferronato G, Manfredini D. Myositis ossificans traumatica of the temporalis muscle: a case report and diagnostic considerations. Oral Maxillofac Surg. 2012 Jun;16(2):221-5. [Medline: 21938392] [doi: $10.1007 / \mathrm{s} 10006-011-0293-6]$

17. Wanyura H, Stopa SZ, Brzozowski F. Limited mouth opening caused by myositis ossificanstraumatica of the temporal muscle - A case report. J Stoma. 2011 Sep; 64:656-6.

18. Manzano D, Silván A, Saez J, Moreno JC. Myositis ossificans of the temporalis muscle. Case report. Med Oral Patol Oral Cir Bucal. 2007 Aug 1;12(4):E277-80. [Medline: 17664912]

19. Uematsu Y, Nishibayashi H, Fujita K, Matsumoto H, Itakura T. Myositis ossificans of the temporal muscle as a primary scalp tumor. Case report. Neurol Med Chir (Tokyo). 2005 Jan;45(1):56-8. [Medline: 15699623] [doi: 10.2176/nmc.45.56]

20. Saka B, Stropahl G, Gundlach KK. Traumatic myositis ossificans (ossifying pseudotumor) of temporal muscle. Int J Oral Maxillofac Surg. 2002 Feb;31(1):110-1. [Medline: 11936393] [doi: 10.1054/ijom.2001.0118]

21. Mevio E, Rizzi L, Bernasconi G. Myositis ossificans traumatica of the temporal muscle: a case report. Auris Nasus Larynx. 2001 Nov;28(4):345-7. [Medline: 11694380] [doi: 10.1016/S0385-8146(01)00059-1]

22. Lello GE, Makek M. Traumatic myositis ossificans in masticatory muscles. J Maxillofac Surg. 1986 Aug;14(4):231-7. [Medline: 3461100] [doi: 10.1016/S0301-0503(86)80295-8]

23. Wiesenfeld D, Evans FJ, Johnson N. Pseudomalignant osseous tumor of the temporalis muscle. J Oral Maxillofac Surg. 1985 Oct;43(10):786-9. [Medline: 3862777 ] [doi: 10.1016/0278-2391(85)90335-0]

24. Fité-Trepat L, Martos-Fernández M, Alberola-Ferranti M, Romanini-Montecino C, Saez-Barba M, Bescós-Atín C. Myositis ossificans of the masseter muscle: A rare location. Report of a case and review of literature. J Clin Exp Dent. 2016 Apr 1;8(2):e210-3. [Medline: 27034763] [PMC free article: 4808318] [doi: 10.4317/jced.52888]

25. Cavalheiro BG, Cernea CR, Brandão LG. Multifocal myositis ossificans in masticatory muscles 30 years after gunshot wound: case report and literature review. Braz J Otorhinolaryngol. 2019 Mar - Apr;85(2):259-262. [Medline: 27177980] [doi: 10.1016/j.bjorl.2016.03.018]

26. Karaali S, Emekli U. Myositis Ossificans Traumatica of the Medial Pterygoid Muscle After Third Molar Tooth Extraction: A Case Report and Review of Literature. J Oral Maxillofac Surg. 2018 Nov;76(11):2284.e1-2284.e5. [Medline: 30076806$]$ [doi: 10.1016/j.joms.2018.06.174]

27. Onishi A, Otsuka Y, Morita N, Morinobu A. Focal myositis diffusely involving multiple masticatory muscles. Scand J Rheumatol. 2018 Nov;47(6):513-514. [Medline: 29400113] [doi: 10.1080/03009742.2017.1397740]

28. Becker OE, Avelar RL, Rivero ER, De Oliveira RB, Meurer MI, Santos AM, Haas Júnior OL, Meurer E. Myositis Ossificans of the Temporalis Muscle. Head Neck Pathol. 2016 Sep;10(3):340-4. [Medline: 26703385] [PMC free article: 4972749] [doi: 10.1007/s12105-015-0675-4]

29. Damian L, Botar Jid C, Rogojan L, Dinu C, Maniu A, Fodor D, Rednic S, Simon SP. Unilateral temporal myositis heralding polymyositis: ultrasonographic and elastographic findings. Case report. Med Ultrason. 2016 Mar;18(1):123-6. [Medline: 26962566] [doi: 10.11152/mu.2013.2066.181.boj] 
30. Wang X, Jiao Z, Wang Y, Zheng J, Zhang S, Yang C. Application of digital medicine techniques in the surgical treatment of myositis ossificans traumatica: a case report and review of the literature. Int J Clin Exp Med. 2016 Dec; 9(12):2371320. [URL: http://www.ijcem.com/files/ijcem0030026.pdf]

31. Demirkol M, Aras MH, Tutar E. Myositis Ossificans Circumscripta in the Masseter Muscle Mimicking Phleboliths. J Craniofac Surg. 2015 Sep;26(6):2020-1. [Medline: 26147036] [doi: 10.1097/SCS.0000000000001897]

32. Ferra M, Costantino PD, Shatzkes D. A Woman With Trismus. JAMA Otolaryngol Head Neck Surg. 2015 Jul;141(7): 665-6. [Medline: 25974619] [doi: 10.1001/jamaoto.2015.0722]

33. Kang JH, Huh KH, Kho HS. Non-infectious myositis of the lateral pterygoid muscle: a report of four cases. Int J Oral Maxillofac Surg. 2015 Feb;44(2):226-8. [Medline: 25457825] [doi: 10.1016/j.ijom.2014.09.023]

34. Mashiko T, Akizuki T, Watanabe Y, Sasaki R, Yokoyama M, Yoshimura K, Mineda K. Clinicopathologic Assessment of Myositis Ossificans Circumscripta of the Masseter Muscles. J Craniofac Surg. 2015 Sep;26(6):2025-6. [Medline: 26147032] [doi: 10.1097/SCS.0000000000001908]

35. Torres AM, Nardis AC, da Silva RA, Savioli C. Myositis ossificans traumatica of the medial pterygoid muscle following a third molar extraction. Int J Oral Maxillofac Surg. 2015 Apr;44(4):488-90. [Medline: 25487562] [doi: 10.1016/j.ijom.2014.11.003]

36. Ahmad K, Ansari S, Dhungel K, Gupta M, Rauniyar R, Amanullah MF. Myositis ossificans traumatica of the left masseter muscle presenting as soft tissue mass: a case report. Bangladesh J Med Sci. 2014 Dec;13(1):73-5. [doi: 10.3329/bjms.v13i1.17441]

37. Almeida LE, Doetzer A, Camejo F, Bosio J. Operative management of idiophatic myositis ossificans of lateral pterygoid muscle. Int J Surg Case Rep. 2014;5(11):796-9. [Medline: 25290385] [PMC free article: 4245686] [doi: 10.1016/j.ijscr.2014.09.008]

38. Boffano P, Zavattero E, Bosco G, Berrone S. Myositis ossificans of the left medial pterygoid muscle: case report and review of the literature of myositis ossificans of masticatory muscles. Craniomaxillofac Trauma Reconstr. 2014 Mar;7(1):43-50. [Medline: 24624256] [PMC free article: 3931776] [doi: 10.1055/s-0033-1356760]

39. Kamalapur MG, Patil PB, Joshi S, Shastri D. Pseudomalignant myositis ossificans involving multiple masticatory muscles: Imaging evaluation. Indian J Radiol Imaging. 2014 Jan;24(1):75-9. [Medline: 24851010] [PMC free article: 4028921] [doi: 10.4103/0971-3026.130706]

40. Spinzia A, Moscato G, Broccardo E, Castelletti L, Maglitto F, Orabona GD, Piombino P. A rare isolated unilateral myositis ossificans traumatica of the lateral pterygoid muscle: a case report. J Med Case Rep. 2014 Jun 26;8:230. [Medline: 24970649] [PMC free article: 4096438] [doi: 10.1186/1752-1947-8-230]

41. Piombino P, Dell'Aversana Orabona G, Abbate V, Fini G, Liberatore GM, Mici E, Belli E. Circumscribed myositis ossificans of the masseter muscle: report of a case. G Chir. 2013 Sep-Oct;34(9-10):271-4. [Medline: 24629814] [PMC free article: 3926482$]$

42. Choudhary AK, Sahoo NK, Chattopadhyay PK. Myositis ossificans traumatica of the medial pterygoid muscle: A case report. J Oral Maxillofac Surg Med Pathol. 2012 Nov; 24(4):241-2. [doi: 10.1016/j.ajoms.2011.12.004]

43. Thangavelu A, Vaidhyanathan A, Narendar R. Myositis ossificans traumatica of the medial pterygoid. Int J Oral Maxillofac Surg. 2011 May;40(5):545-9. [Medline: 21112739] [doi: 10.1016/j.ijom.2010.10.024] [Medline: 21112739]

44. Ramieri V, Bianca C, Arangio P, Cascone P. Myositis ossificans of the medial pterygoid muscle. J Craniofac Surg. $2010 \mathrm{Jul} ; 21(4): 1202-4$. [Medline: 20613616] [doi: 10.1097/SCS.0b013e3181e17cfa]

45. Trautmann F, Moura Pd, Fernandes TL, Gondak RO, Castilho JC, Filho EM. Myositis ossificans traumatica of the medial pterygoid muscle: a case report. J Oral Sci. 2010 Sep;52(3):485-9. [Medline: 20881344] [doi: 10.2334/josnusd.52.485]

46. Bansal V, Kumar S, Mowar A. Unusual causes of trismus: a report of two cases. J Maxillofac Oral Surg. 2009 Dec;8(4): 377-80. [Medline: 23139549] [PMC free article: 3454093] [doi: 10.1007/s12663-009-0091-y]

47. Kruse AL, Dannemann C, Grätz KW. Bilateral myositis ossificans of the masseter muscle after chemoradiotherapy and critical illness neuropathy--report of a rare entity and review of literature. Head Neck Oncol. 2009 Aug 12;1:30. [Medline: 19674466] [PMC free article: 2729737] [doi: 10.1186/1758-3284-1-30]

48. Rattan V, Rai S, Vaiphei K. Use of buccal pad of fat to prevent heterotopic bone formation after excision of myositis ossificans of medial pterygoid muscle. J Oral Maxillofac Surg. 2008 Jul;66(7):1518-22. [Medline: 18571044] [doi: 10.1016/j.joms.2007.05.020]

49. Aoki T, Naito H, Ota Y, Shiiki K. Myositis ossificans traumatica of the masticatory muscles: review of the literature and report of a case. J Oral Maxillofac Surg. 2002 Sep;60(9):1083-8. [Medline: 12216001] [doi: 10.1053/joms.2002.34427]

50. Kim DD, Lazow SK, Har-El G, Berger JR. Myositis ossificans traumatica of masticatory musculature: A case report and literature review. J Oral Maxillofac Surg. 2002 Sep;60(9):1072-6. [Medline: 12215998] [doi: 10.1053/joms.2002.34424]

51. Takahashi K, Sato K. Myositis ossificans traumatica of the medial pterygoid muscle. J Oral Maxillofac Surg. 1999 Apr;57(4):451-6. [Medline: 10199499] [doi: 10.1016/S0278-2391(99)90289-6]

52. Geist JR, Bhatti P, Plezia RA, Wesley RK. Fibrodysplasia ossificans circumscripta of the masseter muscle. Dentomaxillofac Radiol. 1998 May;27(3):182-5. [Medline: 9693532] [doi: 10.1038/sj.dmfr.4600341] 
53. Steiner M, Gould AR, Kushner GM, Lutchka B, Flint R. Myositis ossificans traumatica of the masseter muscle: review of the literature and report of two additional cases. Oral Surg Oral Med Oral Pathol Oral Radiol Endod. 1997 Dec;84(6): 703-7. [Medline: 9431543] [doi: 10.1016/S1079-2104(97)90376-0]

54. Naumann M, Toyka KV, Goebel HH, Hofmann E, Reichmann H. Focal myositis of the temporal muscle. Muscle Nerve. 1993 Dec;16(12):1374-6. [Medline: 8232395] [doi: 10.1002/mus.880161216]

55. Parkash H, Goyal M. Myositis ossificans of medial pterygoid muscle. A cause for temporomandibular joint ankylosis. Oral Surg Oral Med Oral Pathol. 1992 Jan;73(1):27-8. [Medline: 1603562] [doi: 10.1016/0030-4220(92)90149-K]

56. Fujiwara K, Watanabe T, Katsuki T, Ohyama S, Goto M. Proliferative myositis of the buccinator muscle: a case with immunohistochemical and electron microscopic analysis. Oral Surg Oral Med Oral Pathol. 1987 May;63(5):597-601. [Medline: 3295653] [doi: 10.1016/0030-4220(87)90235-0]

57. Arima R, Shiba R, Hayashi T. Traumatic myositis ossificans in the masseter muscle. J Oral Maxillofac Surg. 1984 Aug;42(8):521-6. [Medline: 6588169] [doi: 10.1016/0278-2391(84)90011-9]

58. In: Joanna Briggs Institute Reviewer's Manual. Aromataris E, Munn Z, editors. Moola S, Munn Z, Tufanaru C, Aromataris E, Sears K, Sfetcu R, Currie M, Qureshi R, Mattis P, Lisy K, P-F M. Chapter 7: Systematic reviews of etiology and risk. The Joanna Briggs Institute; 2017. [URL: https://reviewersmanual.joannabriggs.org]

59. Zengin AZ, Celenk P, Sumer AP. Intramuscular hemangioma presenting with multiple phleboliths: a case report. Oral Surg Oral Med Oral Pathol Oral Radiol. 2013 Jan;115(1):e32-6. [Medline: 23217548] [doi: 10.1016/j.0000.2012.02.032]

60. Munhoz L, da Silva Costa CL, Arita ES. Phleboliths in plain radiographs: report of three cases. Rev Fac Odontol Lins. 2018 Jan-Jun;28(1):63-9. [doi: 10.15600/2238-1236/fol.v28n1p63-69]

61. Rajanikanth BR, Prasad K, Vineeth K, Sonale SMN, Al-Kubra K. Unresolving trismus following third molar surgery: Report of a case of fibrodysplasia ossificans progressiva with review of literature. Cranio. 2018 Sep;36(5):341-349. [Medline: 28797219] [doi: 10.1080/08869634.2017.1349025]

\section{To cite this article:}

Ramos EADA, Munhoz L, Milani BA, de Matos FP, Arita ES.

Myositis Ossificans Traumatica of the Temporal Muscle: a Case Report and Literature Review Emphasizing Radiographic Features on Computed Tomography and Magnetic Resonance Imaging

J Oral Maxillofac Res 2019;10(4):e5

URL: http://www.ejomr.org/JOMR/archives/2019/4/e5/v10n4e5.pdf

doi: $10.5037 /$ jomr.2019.10405

Copyright (C) Ramos EADA, Munhoz L, Milani BA, de Matos FP, Arita ES. Published in the JOURNAL OF ORAL \& MAXILLOFACIAL RESEARCH (http://www.ejomr.org), 30 December 2019.

This is an open-access article, first published in the JOURNAL OF ORAL \& MAXILLOFACIAL RESEARCH, distributed under the terms of the Creative Commons Attribution-Noncommercial-No Derivative Works 3.0 Unported License, which permits unrestricted non-commercial use, distribution, and reproduction in any medium, provided the original work and is properly cited. The copyright, license information and link to the original publication on (http://www.ejomr.org) must be included. 